\title{
SECOND TITHE AND WINE: A HISTORICAL AND THEOLOGICAL STUDY OF DEUTERONOMY 14:22-29
}

\author{
Yohanes Verdianto \\ Halmahera University North Maluku, Indonesia \\ Email: yohanesvd@uniera.ac.id
}

\begin{abstract}
Tithing is God's holy, in recognition that God is the owner and man is the servant. But in Deuteronomy 14:22-29 the fact is found that God's holy tithing can be used to buy everything he wants including intoxicating drinks, and even God ordered that the Israelites eat them together with the priests before God. The purpose of the study was to examine the history of the second tithing and its use in Deuteronomy 14:22-29 to find out the true purpose of God's commandments about spending tithing for whatever is desired, spending tithing on intoxicating beverages, and whether this is the legitimacy of God so that His people can currently consume liquor. Research methods are documentary research methods. This is done by evaluating various historical literature in the discussion of tithing festivals and their use. This researcher will conclude research to answer these questions. First of all, in the Bible there are three types of tithing.
\end{abstract}

Keywords: levitical tithe; festival tithe; second tithe; wine; intoxicating drink

Received: 2021-08-22; Accepted: 2021-09-05; Published: 2021-09-20

\section{Introduction}

The tithe is an inseparable part of the life of the Israelites. Once a year they returned the tithe to be used by the Levites and priests along with their families. But a tithe that completely different is found in Deuteronomy 14:22-29, where the tithe money can be used to buy whatever the heart likes, including intoxicating drinks. In addition, this passage seems to provide legitimacy so that God's own people consume intoxicating drinks.

This paper will explore the biblical evidence that explains the tithe system, in order to obtain the theological significance of tithing. Bible scholars give little attention to the study of the tithe system of the nation of Israel. Most studies on this subject are dominated by history, the reconstruction of the history of the tithe, and not on the theological side and the true meaning of tithing itself, (Rodriguez, 1994) especially those found in Deuteronomy 14. Thus, this paper will try to bridge the gap, so that true meaning can be found regarding the tithe found in Deuteronomy 14.

The search for tithe arrives at Deuteronomy 14:22-29 which seems to give a license for God's people to use the tithe that belongs to God for "whatsoever thy soul lusteth after, ... including wine, or for the strong drink" (vv. 26, Italic mine). Using tithe

$\begin{array}{ll}\text { How to cite: } & \text { Verdianto, Y., (2021) Second Tithe and Wine: A Historical and Theological Study of Deuteronomy } \\ & \text { 14:22-29. Syntax Idea, 3(9), https://doi.org/10.36418/syntax-idea.v3i9.1462 } \\ \text { E-ISSN: } & \text { 2684-883X } \\ \text { Published by: } & \text { Ridwan Institute }\end{array}$


money that belongs to God, to buy everything you like even to buy liquor. Of course, this is an interesting thing to explore.

There have been several previous studies discussing tithing (Tvedtnes, 1996) but they have not touched the realm of the use of tithe for intoxicating drinks, including whether it is true that God allows His people to consume it. Start with this, there are questions that will be discussed in this paper, namely: Why tithe can be used to buy personal needs including intoxicating drinks? Does God giving legitimacy to his people now to consume liquor?

\section{Research Methods}

The method of research used in this article is a documentary research method. This method will evaluate various historical literature that discusses the tithe festival and its use. Likewise various comments relating to the tithe in Deuteronomy which distinguishes it from tithe in the books of Leviticus and Numbers.

\section{Results and Discussions}

\section{History of the Tithe}

Tithe, from Old English teogothian, "tenth," is a custom dating back to Old Testament times and adopted by the Christian church whereby lay people contributed a 10th of their income for religious purpuses, often under ecclesiastical or legal obligation (Brian Dugnan, 2021). In its history, tithing is not an exclusive practice of the Israelites. Records from the city of Ugarit in the 14th century BC indicate that the residents of the city paid tithing to the temple, this was a kind of tax; (See Jacob Milgrom, 1999) and the king also receives a royal tax (10\%) from his people (Gary A. Anderson, 1987). Neo-Babylonian documents from the 6th century $\mathrm{BC}$ state that tithing was a common practice in Babylon. The tithe is given to the temple, and the king himself is also tithed. Tithes are collected from everything, including wheat, dates, sesame, linen, oil, onions, wool, clothing, livestock, sheep, birds, wood, and gold and silver products (See Jacob Milgrom, 1999). Even tithing is already known and practiced in Persia, Greece, and Rome (Tvedtnes, 1996).

Enclyclopedia of Religion explains the same thing that in the ancient Near East lie the origins of a sacral offering or payment of a tenth part of stated goods or property to the deity. The tithe is often given to the king or to the royal temple. The practice is known from Mesopotamia, Syria-Palestine, Greece, and as far to the west as the Phoenician city of Carthage. The origin of the tithe is not to the Levites, for previously kings received a tenth from their peoples. The Temple Scroll from Qumran requires that a tenth of the booty from war be given to the king, a thousandth to the priests, a hundredth to the Levites, with half of the remainder going to those who fought in battle and the other half to those who remained behind in the cities. 
The Old Testament references to the tithe are few in number and somewhat indefinite in character. The oldest law on the subject is that of Deuteronomy (12:6, $17 ; 14: 22,28 ; 26: 12)$. The only other legislation is in P, viz., Num. 18:21-26 and Lev. 27:30-33. The legislation of J (Exod., chap. 34) and of E (Exod., chaps. 20-23) contains no allusion to it. Yet that there was payment of tithes prior to the requirements of the Deuteronomic law is practically certain. The story of Jacob at Bethel (Gen. 28:22) seems to testify clearly to the custom of paying tithes at the shrine there in early times. This conclusion is strengthened by Amos 4:4, which testifies to the custom as practiced at both Bethel and Gilgal in the eighth century B.C. The antiquity of tithing in Israel is also supported by Gen. 14:20, which records that Abraham paid tithes of his booty to Melchizedek, the priest-king of Salem. But this support is a slender one in the present state of opinion regarding the date and character of this chapter. In view of these slight data and of the fact that tithing was a widely spread custom in the ancient world (W., 1901) it is safe to conclude that a tithe was paid at the various local shrines in Israel long prior to the Deuteronomic reformation (W., 1901).

Furthermore, the Bible historians also cannot be able to know with certainty the origin of this tithing practice. The Bible also does not tell it with certainty, and when tithing is first mentioned in the Bible, it seems that it is a practice that is commonly practiced. One thing we know that "the tithing system reaches back beyond the days of Moses. ... Even as far back as the days of Adam." (Nichol, 1898) This tithing system, as stated in the Old Testament, comes from God, was given by God to human beings. It seems that tithing is related to humanity in its fallen state. Angel M. Rodriguez stated that "It is in the context of the most disturbing tragedy that for very specific reasons, the system of tithes and offerings was instituted by God (Rodrìguez, 1994)" If history cannot trace the true origin of tithing, then it is safe to conclude that the tithing system was actually instituted by God Himself.

\section{Tithes in the Bible}

Speaking of tithe, the important question that arises is how many times does tithe be given by the Israelites to God? Albert Barnes comments on Matthew 23:23 as follows,

The law required the Jews to devote a tenth part of all their property to the support of the Levites, Numbers 18:20-24. Another tenth part they paid for the service of the sanctuary, commonly in cattle or grain, but where they lived far from the place of worship they changed it to money, Deuteronomy 14:22-24. Besides these, there was to be every third year a tenth part given to the poor, to be eaten at their own dwellings Deuteronomy 14:28-29; so that nearly one-third of the property of the Jews was devoted to religious services by law. This was besides the voluntary

offerings which they made (https://www.studylight.org/commentaries/bnb/matthew23. html, 2020). 
Almost in line with Barnes, the early church historian, Flavius Josephus stated that Moses specifically wrote about three types of tithe: "one for the Levites and the other for the banquets, ... (and one) to widowed women and orphan children."(Josephus, 1958). Rodriguez has a similar view that tithing for the Levites is found in the book of Leviticus and Numbers, while tithing for ministry and for those who in need is found in Deuteronomy. It is clear that there are significant differences between the tithe legislation found in Deuteronomy and that found in the book of Leviticus and Numbers (Rodrìguez, 1994). He gives at least three reasons why tithing in Leviticus and Numbers is different from tithing in Deuteronomy.

a. Objects of Tithe: In Deuteronomy tithe was imposed only on grain, wine, and oil, while in the other legislation all the produce of the earth and the increase of herds and flocks were to be tithed.

b. Levitical Tithe: Although the tithe discussed in Deuteronomy was required by the Lord, it belonged to the family that brought it to the sanctuary. Leviticus and Numbers deal with a tithe that belonged exclusively to God, and that was given by Him to the Levites and priests.

c. Fellowship Meals: Tithe in Deuteronomy was to be used by the Israelites for a family fellowship meal to be eaten at the central sanctuary. The other legislations did not allow for that. They limited the eating of the tithe to the Levites, the priests, and their respective families.

It is seems that we are dealing with two different types of tithe. Rabbinic traditions called the tithe recorded in Leviticus "the first tithe," and the one in Deuteronomy "the second tithe." Thus, at least three tithes were made by the Israelites in Bible times, namely:

1. Tithe for the Levites (Leviticus 27: 30-33; Numbers 18: 21-32) - Sacred tithe / Levitical tithe.

2. The second tithe (Deuteronomy 14: 22-27) - Annual feasts / Festival tithe.

3. Additional tithes every third year (Deuteronomy 14: 28-29) - Second tithe for charity / Tithe for the poor.

If it can be abbreviated, the three types of tithing are: "first tithe," "second tithe," and "poor tithe";(Sanders, 2016) where the designation is as follows, "first, God; second, man's own physical and spiritual welfare; and third, their neighbor's need. God, you, and your neighbor are a good trinity in planning one's giving." The giving of tithes by the Israelites can be seen in the table below:

\begin{tabular}{llllllllll}
\hline No. & Tithe & \multicolumn{1}{c}{ Hebrew } & & \multicolumn{1}{c}{ Years } \\
\hline & & & 1 & 2 & 3 & 4 & 5 & 6 & 7 \\
\hline 1 & Leviticus & ma'aser rishon & $*$ & $*$ & $*$ & $*$ & $*$ & $*$ & $*$ \\
\hline 2 & Second & ma'aser sheni & $*$ & $*$ & & $*$ & $*$ & & \\
\hline 3 & Third & ma'aser ani & & & $*$ & & & $*$ & \\
\hline
\end{tabular}


The first tithe is exclusive to the priests. One illustration of this usage of tithe is found in the book of Tobit. Tobit is said to have gone to Jerusalem "with the first fruits and the tithes of the increase and the first shearings of the sheep," which he gave to the priests, the sons of Aaron (1:6-7). Yet immediately afterward he states that he gave the tithe to the sons of Levi, who ministered in Jerusalem (1:7). The writings of Josephus are another source that is frequently cited as reflecting the Levitical tithes to the priests. In Antiquities of the Jews Book XX, Josephus refers to high priests who sent their slaves to the threshing floors to receive "the tythes [sic] that were due to the Priests." (Josephus, 1958).

The second tithe found in Deuteronomy 14:22-27 gives some questions that are enough to shake the Christian faith. This is especially stated in verses 26-27, that is to spending tithe to buy "wine, or for strong drink, ... and thou shalt eat there before the LORD thy God, ... And the Levite that is within thy gates; thou shalt not forsake him." Can we use tithe that is God's money to buy strong drink and event to consume it with the Levites before the Lord? Let us examine it.

\section{Second Tithe}

The new thing regarding tithing in Deuteronomy is "the transfer of the offering of the tithe from the local shrines to the central sanctuary at Jerusalem (Todaro \& Smith, 2013)" In the book Tobit, which according to R. H. Charles was written between 350-170 BC, (Samuel R. Driver, 1896) there is the following sentence: "And the second tithe I tithed in money for the six years, and spent it each year at Jerusalem." In this case, the second tithe is brought to the place appointed by God, that is, the place where the sanctuary is established.

This second tithe, in two years they must take it to the place where the sanctuary is located as a thanksgiving offering and eat it in a religious ceremony or festival, in which the Levites, foreigners, orphans, and widows must take part. Then in the third year, this second tithe must be used in the household, to entertain the Levites and the poor, so "that they may eat within thy gates, and be filled," (Deut. 26:12), and to provide one fund to use for social purposes and virtues.

Deuteronomy 12:17-19 introduces the second tithe, which is explained more detail in Deuteronomy 14:22-27. This tithe is different from the tithe found in Numbers 18:21. In Numbers 18, God gave that tithe to the Levites for their lives because they served the nation of Israel; whereas in Deuteronomy 14:22-27, those who bring tithing to take part in it (Croteau, 2005). Besides that, in Numbers 18:31 it is said to the Levites that they could eat the tithe "in every place"; whereas in Deuteronomy 14:23 the tithe must be taken "in the place which he shall choose." Likewise, the tithe in Numbers 18 belongs to the Levites; whereas in the book of Deuteronomy the tithe remains as the property of the giver of the tithe. Finally, while the purpose of tithing in Numbers 18 is to give an inheritance to the Levites and priests; whereas the purpose of the second tithe in Deuteronomy stated in Deuteronomy 14:23, "that thou mayest learn to fear the LORD thy God always." For more details, see the table below: 


\begin{tabular}{llll}
\hline No. & & \multicolumn{1}{c}{ Numbers 18 } & \multicolumn{1}{c}{ Deuteronomy 14 } \\
\hline 1 & Type & First tithe & Second and third tithe \\
& & Levitical tithe & Festival tithe \\
\hline 2 & Allocation & Levites and priests & The tithe giver \\
\hline 3 & Location & In every place & $\begin{array}{l}\text { In the place which he shall } \\
\text { choose }\end{array}$ \\
\hline 4 & Purpose & $\begin{array}{l}\text { To give an inheritance to the } \\
\text { Levites and priests }\end{array}$ & $\begin{array}{l}\text { So that you may learn to } \\
\text { fear the Lord }\end{array}$ \\
\hline
\end{tabular}

The differences between the Levitical and Festival tithe, for summary we can see in the table below:

\begin{tabular}{llll}
\hline No. & \multicolumn{1}{c}{ Levitical Tithe } & \multicolumn{1}{c}{ Festival Tithe } \\
\hline 1 & Objects of tithe & $\begin{array}{l}\text { All the produce of the earth } \\
\text { and the increase of the } \\
\text { herds and flocks }\end{array}$ & $\begin{array}{l}\text { Mainly on grain, wine, and } \\
\text { oil. Only the tithe of the } \\
\text { firstborn from the herd was } \\
\text { required }\end{array}$ \\
\hline 2 & Ownership & $\begin{array}{l}\text { It was belonged exclusively } \\
\text { to God. It was given by but belonged to the family }\end{array}$ \\
& $\begin{array}{l}\text { Him to the Levites and } \\
\text { priests }\end{array}$ \\
\hline 3 & Fellowship meals & $\begin{array}{l}\text { It was limited the eating of It was to be used for a } \\
\text { the tithe to the Levites, the family fellowship meal - at } \\
\text { priests, and their respective the sanctuary. } \\
\text { families }\end{array}$ \\
\hline
\end{tabular}

However, both the tithes in Deuteronomy 12 and 14, the Israelites were advised not to ignore the Levites and priests. Thus, both the tithe in Numbers and in Deuteronomy supported the Levites and also the priests (Barker, 1979). Deuteronomy 14: 22-27 describes how Israelites' festivals took place. On the appointed days, the Israelites will go to the place determined by the LORD and celebrate the party or festival there. They either take their second tithe there or sell it for money and buy whatever ("whatsoever thy soul desireth") that they want to eat. There is no mention of tithing from animals here because they must offer tithes from animals as first fruits and tithes for the Levites (Croteau, 2005).

Libson discusses a similar function of the second tithe, that the second tithe appears to have an exclusively religious purpose of bringing the fruits to the holiest city (Libson, 2014). The role of the second tithe in removing barriers between classes of people emerges. Thus, the second tithe serve to embed in people a psychological recognition of different socioeconomic experiences that helps to forge a sense of belonging among people of different classes (Libson, 2014). 


\section{The Purpose of the Second Tithe}

Talking about the purpose of the first tithe, it seems there is no question. But what about the second tithe? Why did God ordered Moses to tell the Israelites to give a second tithe? This section will evaluate what is the purpose of giving a second tithe. As discussed earlier, the second tithe consists of two parts, namely tithe for every first and second year; and tithe for every third year. And this repeats in a seven-year cycle (See Geoffrey Wigoder, 1989) In the seventh year, all that was produced by the land was dedicated to the poor and the needy (Exodus 23: 1011).

\section{a. Generosity and Philanthropic}

Regarding the second tithe, Deuteronomy 14:23, 26, 27 says that "thou shalt eat before the LORD thy God, ... and thou shalt rejoice, thou, and thine household, together with the Levite that is within thy gates" (italics mine). Besides that, this second tithe, every third and sixth year in the seven-year cycle of the Israelites, they must take everything out of all tithe offerings from the produce of their land and put it in the city where they live. So the Levites, strangers, orphans and widows, and those who are poor and needy can take it and eat until they are full. This indicates that Israel "surely was to be a giving nation. ... Generosity, both toward God and man!”(Bruce Oberst, 1968).

When they prosper because of God's mercy, it is their duty to pay attention to those who are in need. In this way, the second tithe was fully applied to alleviate the needs of people who did not own land and live in poverty, whose sufferings so often made the prophet Moses pity them. So the strangers, orphans, and widows, not less than the Levites, are constantly the philanthropic objects of the Pentateuch writers (Samuel R. Driver, 1896).

\section{b. Fear of the Lord}

God emphasized the Israelites to bring the second tithe to the sanctuary, and eat it together with the priest before the Lord. This experience was designed by God to teach them to always respect (literally, "fear," see Deut. 4:10) to the Lord their God. When they eat the food before God with the priest, they will realize and admit that their food (and even their lives) does not depend on their agricultural expertise but on God's blessing. So they will learn to fear Him because only by obeying Him they can continue to eat and live in prosperity (Missler, 2004). This was necessary so that the Israelites would avoid honoring the Canaanite fertility deities for their abundant harvest, (Hoff, 2018) - because data from the Semitic region showed an attempt to offer one-tenth of their agricultural produce to the gods so that their agricultural products would still be blessed, (Pfeiffer, 1934)- but because of God's blessings to them. In this case, they will respect (fear) God.

In what way did observing this second tithe commandment, the Israelites learn to fear God (Deut. 14:23)? God is the owner of the land (or Landlord), and He provides that His servants, the Levites, will receive blessings from its bounty. 
God wants His people to use what He has given them to provide for others as well as for themselves (Eugene H. Merrill, 1994). In this way, they show respect (fear) to God. Keil and Delitzsch said that "The fear of the Lord is not merely a feeling of dependence on Him, but also includes the notion of divine blessedness, which is the predominant idea here, as the sacrificial meals were to furnish the occasion and object of rejoicing before the Lord (Leschert, 1991)."

\section{c. God's Care for the Poor}

To promote the assembling of the people for religious service, as well as to provide for the poor, the second tithe of all the increase was required. Concerning the first tithe, the Lord had declared, "I have given the children of Levi all the tenth in Israel." Numbers 18:21. But in regard to the second He commanded, "Thou shalt eat before the Lord thy God, in the place which He shall choose to place His name there, the tithe of thy corn, of thy wine, and of thine oil, and the firstlings of thy herds and of thy flocks; that thou mayest learn to fear the Lord thy God always." Deuteronomy 14:23, 29; 16:11-14. This tithe, or its equivalent in money, they were for two years to bring to the place where the sanctuary was established. After presenting a thank offering to God, and a specified portion to the priest, the offerers were to use the remainder for a religious feast, in which the Levite, the stranger, the fatherless, and the widow should participate. Thus provision was made for the thank offerings and feasts at the yearly festivals, and the people were drawn to the society of the priests and Levites, that they might receive instruction and encouragement in the service of God (Nino, 2017).

\section{Second Tithe and Wine}

After tracing the history and purpose of the second tithe, now we will discuss another important part in Deuteronomy 14: 26-27, where there is order about the second tithe so that the tithe money is used to buy "wine, or for strong drink, ... and thou shalt eat there before the LORD thy God ... thou, and thine household, and the Levite that is within thy gates." These verses states that tithe money can be used to buy intoxicating drinks, and drink them before the Lord together with the family and also the Levites. Does God here give licenses to Abraham's children to consume intoxicating drinks? How do you align this command with other instructions in the Scriptures not to consume intoxicating drinks? Here we will examine it.

In Deuteronomy 14:26, there are two words relating to different types of drinks, namely "wine and strong drink." The two words in Hebrew are, "yayin" and "sekhar (Missler, 2004)." Lange in his comment said that "The distinction here is not between two kinds of wine, one intoxicating and the orther not, but between wine and a drink made from some other substance than the grape (Lange, 1893)." It can be made from honey or wheat (Lange, 1893) or dates (Gesenius, 1968).

a) Wine 
The first part that we will examine is "wine." Bob Utley in his writings on Deuteronomy, in the passage on First Century Jewish Culture and Fermentation, discusses wine fermentation. There he asserted that "fermentation begins very soon, approximately 6 hours after the grape is crushed." But this is not intoxicating wine. Talking about this, Mishnah states that the Jewish tradition says that the wine intended here is "when a slight foam appears on the surface (a sign of fermentation), it is the wine-tithe. ... It was called 'new wine' or 'sweet wine (Herbert Danby, 2011). Samuel A. Kaplan, a Jewish Minister, explained this as follows, "Ya-een, or wine, covers a variety of meanings. It is used in Scripture to mean the pure juice of grapes (Ex. 29:40), fermented wine (Joshua 9:13), pure doctrine (Isa. 55: 1) (Samuel A. Kaplan, 1937)."

In his investigation regarding this matter, Samuele Bacchiocchi said that,

I investigated the Biblical and historical usage of the term "wine," beginning from the English wine, and then proceeding backward to the Latin vinum, the Greek oinos, and finally the Hebrew yayin. The result of the survey is abundantly clear: these four related words have been used historically to refer to the juice of the grape, whether fermented or unfermented (Akers et al., 1995).

Bacchiocchi says that in the Bible and history, the term "wine" in various languages explains that "wine" historically refers to grape juice, both fermented and unfermented.

For example, The New Webster Encyclopedic Dictionary of the English Language (1971) defines "wine" as "juice pressed from the grapes but not fermented." Here it can be seen that the definition of "wine" is clearly used "to denote unfermented grape juice." In line with this, The Jewish Encyclopedia says that the term "wine" is used to refer to both fermented and unfermented wines. It says that "Fresh wine before fermenting was called "yayin mi-gat (Dauge-Roth, 2019)" "So in this case, yayin means wine or unfermented grape juice. Furthermore, Halakot Gedalot, which is the earliest summary of the Jewish Talmud says that, "One may press out a cluster of grapes and pronounce the Kiddush over the juice, since the juice of the grape is considered wine [yayin] in connection with the laws of the Nazirite (Ginzberg, 1923)"

It is clear that the Jewish tradition states that the tithes referred here are new grapes, and sweet grapes, even though (maybe) fermented; and it is not bitter, or high alcoholic wine.

b) Strong Drink

Now we will examine the word sekhar, "intoxicating drinks" ("strong drink," KJV, NASB, RSV). Modern Bible scholars think that the word sekhar refers to "distilled liquor (Missler, 2020)." But that is not what the Bible means, because the alcohol distillation process was only used in the Near East around the 7th century CE (Smith, 2017). This fact shows us that the scriptural 
terminology "strong drink", certainly gives us no license to drink what we know today as hard liquor (William H. Shea, 2020).

If distilled alcohol is not what the Bible means about the word shekar, then what is the definition of the word shekar? Samuel A. Kaplan explains that the Hebrew word "shai-chor," means "satisfaction, satiation, sweetness. Haggai 1: 6. The English word 'sugar,' the German word 'zucher,' and the Greek word 'sikera' (sweet wine) are all quite similar to the Hebrew Shai-cha. The old wine was sweeter, more satisfying, than the new wine (see Luke 5:39)." This is accordingly with what was conveyed by Deere, in his commentary on Deuteronomy, he stated that "the beverages in view here were not high in alcohol content."

In his commentary about the word shekar, Missler explained that because alcohol was only discovered around the $7^{\text {th }}$ century CE, shekar here means "fermented drink." He further explained that "The fermented drink was probably a kind of beer (this is usual NIV trans.), brewed by ancient Egyptians and Akkadian, and therefore low in alcohol content (Missler, 2020)." Kaplan then goes on to comment that "Although 'shai-chor' is used in the Bible many times, meaning intoxicating drinks, it is also used to designate sweet, old wine. (See Numbers 28: 7)." So the word shekar is meant here as a fermented drink, even though it is not strong drink and intoxicating.

Certainly, God would not advocate in one Scripture that which $\mathrm{He}$ unequivocally condemns in all all other parts of the Scriptures (See Prov. 21:1; Hab. 2:5; Isa. 5:22). Deuteronomy 29:5-6 says that, "And I have led you forty years in the wilderness: your clothes are not waxen old upon you, and thy shoe is not waxen old upon thy foot. Ye have not eaten bread, neither have ye drunk wine or strong drink: that ye might know that I am the LORD your God." Samuele Bacchiocchi in the conclusion of his article about alcohol in the Bible states that, "The Biblical teachings regarding the use of alcoholic beverages can be summarized in one sentence: the Scripture is consistent in teaching moderation in the use of wholesome, unfermented beverages and abstinence from the use of intoxicating beverages." This shows that the word shekar also refers to sweet and old wine, it is maybe fermented, but not an intoxicating drink.

After seeing the two words in Deuteronomy 14:26, namely "yayin" and "sekhar," it can be concluded that God is not giving legitimacy to the Israelites to consume intoxicating alcoholic drinks. Nor this is a legitimacy to drink what we know today as hard liquor. But these two words refer to old, sweet wine, and are not intoxicating drinks, even though it is fermented.

\section{Conclusion}

The main problem of the study was to trace tithing in the Bible especially in Deuteronomy 14:22-29. The main question is why can tithing be used to buy personal 
Second Tithe and Wine: A Historical and Theological Study of Deuteronomy 14:22-29

necessities including intoxicating drinks? Does God give legitimacy to His people now to consume liquor? This section will conclude research to answer these questions. First of all, in the Bible there are three types of tithing. The three types of tithing are as follows: Tithing for Levites (Leviticus 27:30-33; Numbers 18:21-32) - Holy tithing/ Levitical tithing. Second tithing (Deuteronomy 14:22-27) - Annual Feast/Tithing Festival. Additional tithing every third year (Deuteronomy 14:28-29) - Second tithing for charity/Tithing for the poor. If it can be abbreviated, then the three types of tithing are: the first tithing, for God; second tithing, for the physical and spiritual well-being of the tithe; and the third tithing, to meet the needs of others in need. 


\section{BIBLIOGRAFI}

Akers, George H., Alomía, Merling, Archer, Gleason L., Ashworth, Warren S., Bacchiocchi, Samuele, \& Baldwin, John T. (1995). JATS Cumulative Index By Author: 1990œ2004. Conscience, 6(2), 63-76.Google Scholar

Barker, David G. (1979). The Old Testament Hebrew Tithe. Grace Theological Seminary. Google Scholar

Brian Dugnan, Ed. (2021). "Tithe," in Enclyclopedia Britannica. Https://Www.Britannica.Com/Topic/Tithe.

Bruce Oberst. (1968). Deuteronomy. Joplin, MO: College Press. Google Scholar

Croteau, David A. (2005). A biblical and theological analysis of tithing: Toward a theology of* giving in the New Covenant era. Southeastern Baptist Theological Seminary. Google Scholar

Dauge-Roth, Katherine. (2019). Signing the Body: Marks on Skin in Early Modern France. Routledge. Google Scholar

Eugene H. Merrill. (1994). "Deuteronomy, New Testament Faith, and the Christian Life," in Charles H. Dyer and Roy B. Zuck, eds., Integrity of Heart, Skillfulness of Hands. Grand Rapids, MI: Baker Book House.

Gary A. Anderson. (1987). Sacrifices and Offerings in Ancient Israel. Atlanta, GA: Scholars Press. Google Scholar

Gesenius, Wilhelm. (1968). Gesenius' Hebrew Grammar, in Deuteronomy, Bruce Oberst, ed. Joplin: College Press. Google Scholar

Ginzberg, Louis. (1923). A Response to the Question Whether Unfermented Wine May Be Used in Jewish Ceremonies. American Jewish Year Book, 414. Google Scholar

Herbert Danby. (2011). “Maaseroth 1:7 (Tithes)," in The Mishnah. Peabody, MA: Hendrickson Publisher.

Hoff, Nathan N. (2018). One gospel: Paul's use of the Abraham story in Romans 4: 125. Dallas Theological Seminary. Google Scholar

https://www.studylight.org/commentaries/bnb/matthew-23.html. (2020). r

Josephus, Flavius. (1958). Antiquities of the Jews, iv.240, in C. G. Tuland, "The Three Tithes of the Old Testament." The Ministry. 42-43.

Lange, Johann Peter. (1893). A Commentary on the Holy Scriptures: Critical, Doctrinal, and Homiletical: The Minor Prophets (Vol. 14). C. Scribner \& Company. Google Scholar 
Second Tithe and Wine: A Historical and Theological Study of Deuteronomy 14:22-29

Leschert, Dale Frederick. (1991). Hermeneutical foundations of the Epistle to the Hebrews: a study in the validity of its interpretation of some core citations from the Psalms. Fuller Theological Seminary, School of Theology. Google Scholar

Libson, Adi. (2014). Transforming Social Welfare Policy: The Sages'reconstruction Of The Institution Of The Second Tithe As A Model For Social Welfare Policy. Journal of Law and Religion, 29(2), 259-275. Google Scholar

Missler. (2020). Supplement Notes: The Book of Deuteronomy, 82; William H. Shea, "Beer and Wine: The Bible's Counsel," Signs of the Times. Retrieved from https://adventistbiblicalresearch.org/materials/practical-christian-living/beer-andwine-bibles-counseling.

Missler, Chuck. (2004). The Book of Deuteronomy. Google Scholar

Nichol, Francis D. (1898). SDA Bible commentary. Washington: Review and Herald Pub. Association, 1100, 1101. Google Scholar

Nino, Mario. (2017). The Second Tithe: Origin and Purpose. Dynamic Steward, 21(3), 14-15. Google Scholar

Pfeiffer, Robert H. (1934). The History, Religion, and Literature of Israel. Research in the Old Testament, 1914-1925. Harvard Theological Review, 27(4), 241-325. Google Scholar

Rodriguez, Angel. (1994). Stewardship roots: Toward a theology of stewardship, tithe, offerings. Stewardship Ministries, Department of Church Ministries, General Conference. Google Scholar

Rodrìguez, Àngel M. (1994). Stewardship Roots. Stewardship Ministries, Department of Church Ministries, General Conference. Google Scholar

Samuel A. Kaplan. (1937). "Second Tithe, and Wine," The Ministry 10.

Samuel R. Driver, Alfred Plummer and Charles A. Briggs. (1896). The International Critical Commentary: Deuteronomy. Edinburgh: T \& T Clark. Google Scholar

Sanders, Ed Parish. (2016). Jewish law from Jesus to the Mishnah: five studies. Fortress Press. Google Scholar

See Geoffrey Wigoder, ed. (1989). The Encyclopedia of Judaism. New York, NY: Macmillan Publishing Company.

See Jacob Milgrom. (1999). Numbers: The JPS Torah Commentary. New York: NY: Jewish Publication Society. Google Scholar

Smith, Gary. (2017). Continuing to Preach like the Prophets. Preaching Like the 
Prophets: The Hebrew Prophets as Examples for the Practice of Pastoral Preaching, 140. Google Scholar

Todaro, Michael P., \& Smith, Stephen C. (2013). Pembangunan ekonomi edisi kesembilan. In Erlangga. Google Scholar

Tvedtnes, John A. (1996). The priestly tithe in the first century AD. Brigham Young University Studies, 36(3), 261-268. Google Scholar

W., Johns C. H. (1901). Assyrian Deeds and Documents. Facsimile Originally. Google Scholar

William H. Shea. (2020). “Beer and Wine: The Bible's Counsel,” Signs of the Times. Retrieved from https://adventistbiblicalresearch.org/materials/practical-christianliving/beer-and-wine-bibles-counseling.

\section{Copyright holder: \\ Yohanes Verdianto (2021) \\ First publication right: \\ Syntax Idea}

This article is licensed under:

(c) (i) (?) 